\title{
18. Managing Economic Change and Mitigating Climate Change: China's strategies, policies and trends
}

\author{
Fergus Green and Nicholas Stern ${ }^{1}$
}

\section{Introduction}

The year 2015 marked a turning point in China's role in both contributing to and responding to global climate change. As we illustrate in this chapter, China's coal consumption fell significantly in 2015; history will likely show that it peaked in 2013-14. That downturn in coal consumption is a consequence of profound change in Chinese economic activity and also in government strategy and policy across a wide range of issues that extend far beyond a narrow understanding of 'climate policy'. The purpose of this chapter is to explain these changes and to trace their implications for climate change mitigation in China, especially over the next decade.

To do so, we analyse both demand-side and supply-side factors affecting greenhouse gas (GHG) emissions. While the business and economic communities have made much of the changes and challenges relating to China's economic activity in the period since 2014, most of those in the climate policy world have focused primarily on policies and investments affecting the energy supply mix, attending much less to the effects of wider economic changes on China's demand for energy. Yet the relationships between overall economic activity, industrial composition, the government's economic strategy and policies and energy demand form a key part of the story of China's turnaround on climate change. The first part of the chapter is therefore dedicated to a discussion of the demand side. As well as explaining the underlying factors and mechanisms at play, we draw on recent data and policy announcements to forecast the direction of key, climate-relevant demand-side trends over the next decade and consider some of the risks and opportunities that could arise over this period.

The second part of the chapter turns to the supply side-again focusing on energy and industry. In this section, we discuss China's targets, policies and investments with regard to both energy supply and GHG emissions per se.

1 The authors are grateful to Patrick Curran for his guidance and support in preparing this article, and to Lauren Johnston for constructive comments on the penultimate draft. 
We also consider recent developments in the electricity and heavy industry sectors and draw on these to forecast key trends, risks and opportunities over the coming decade. This section of the chapter brings us more squarely into the domain of 'climate policy' as traditionally conceived, though we stress that, even here, China's actions must be understood as products of disparate (yet convergent) motivations, of which mitigating climate change is only one.

The chapter concludes with a brief discussion of some implications of our analysis for China and for global efforts to mitigate climate change.

\section{The demand side: Patterns in growth and energy consumption}

Previous editions of this book series have drawn attention to the change in China's growth model that has begun to occur in recent years. The previous growth model was characterised by rapid, 'catch-up' growth in gross domestic product (GDP) frequently registering double-digit rates, very high savings and investment rates, exceptionally low proportions of expenditure on domestic consumption, high profit shares of income and a strong export orientation (Garnaut et al. 2013, 2014). In the period 2000-13, China also made huge investments in heavy manufacturing industries such as steel and cement production - which consume large amounts of electricity and direct fossil fuel inputs - and in the expansion of coal-fired power generation to supply electricity to those industries (CCICED 2014; Guan et al. 2014). A further wave of investment in infrastructure, building construction and heavy industry was stimulated by the government's response to the drop in Chinese exports caused by the Global Financial Crisis of 2007-08.

This model of growth brought with it benefits such as job creation and poverty reduction; however, there is now widespread recognition within China that this model is neither sustainable nor desirable due to a combination of its economic, financial, social, local environmental and global climate impacts, which have been much discussed elsewhere (see, for example, Green and Stern 2016: 3-4).

The economic and financial legacies of the old model include widespread excess capacity in the construction and heavy industry sectors, diminishing returns on capital investment, weak productivity growth and mounting debtrelated problems (CCICED 2014; IMF 2015; Pettis 2013). These problems have become acute at a time when China has also faced a difficult external economic environment. Further, it is approaching a Lewis turning point (Lewis 1954) in relation to the allocation of labour in the process of growth as the working-age population begins to decline and the large pools of 'surplus' labour migrating 
from the countryside to urban areas begin to dry up, putting upward pressure on wages and signalling the beginning of the end of the low-wage exportoriented manufacturing dimension of China's growth model (Das and N'Diaye 2013; Garnaut and Song 2006; Huang and Cai 2014). In short, the main drivers of the old model - capital investment focused on construction, infrastructure and heavy industry, along with cheap labour and low value-added exportsare slowing or, in some sectors, going into reverse.

These changes in economic activity have been met with the articulation and, increasingly, implementation of a new economic strategy by China's current generation of leaders (CCCP 2013; State Council 2013; Zhang 2014; and see Kuijs 2015). Together, the changes in activity and strategy add up to a new model of growth (Garnaut et al. 2013; cf. Hu 2015). This 'new normal' is understood in Chinese policymaking circles as involving a shift towards economic growth of a higher quality but lower rate, with a particular emphasis on four subthemes: services, innovation, reduced inequality and environmental sustainability (see Green and Stern 2016: 4-5). These themes feature strongly in China's Thirteenth Five-Year Plan (FYP), released in March 2016.

The nature, scale and pace of change in China's economy, and their implications for energy demand, can be gleaned from an analysis of recent Chinese economic data and associated dynamics from the period 2014-15, especially when these are compared with the period of growth from 2000 to 2013, in which there was a strong focus on heavy industry.

\section{Demand-side change: GDP, energy intensity and energy consumption}

The extent of change on the demand side over the past two to three years is illustrated by Figures 18.1-18.3, showing, respectively, growth rates in China's: 1) GDP; 2) energy intensity of GDP (which exhibits negative growth); and 3) total primary energy consumption (PEC) (which is the product of GDP and energy intensity). 


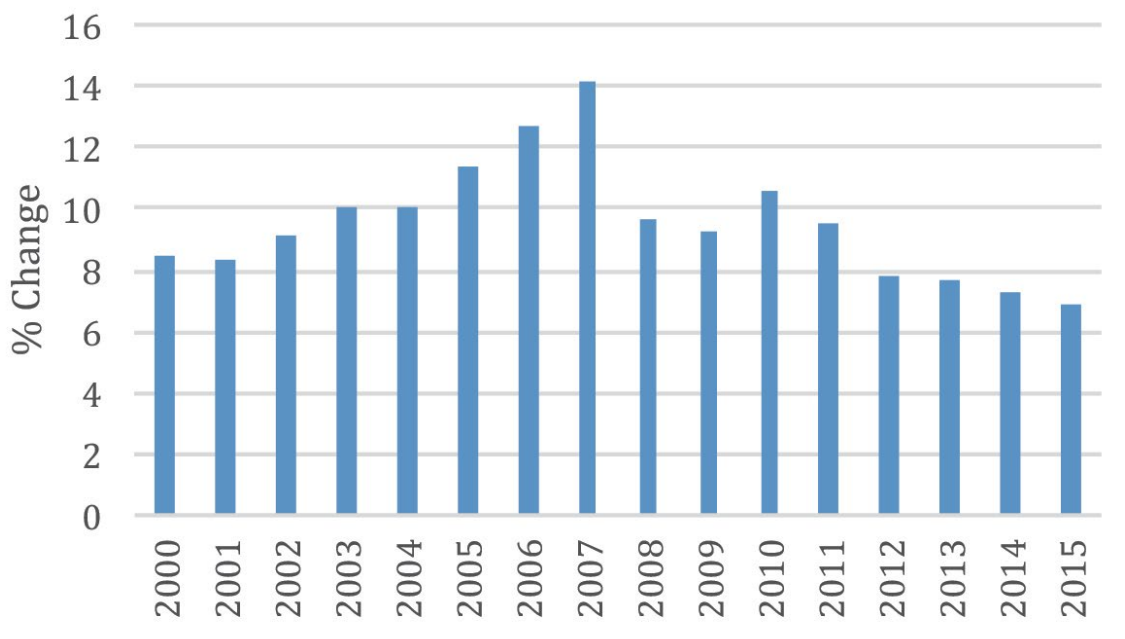

Figure 18.1 Chinese GDP growth rates, 2000-15

Sources: World Bank (2016); NBS (2016).

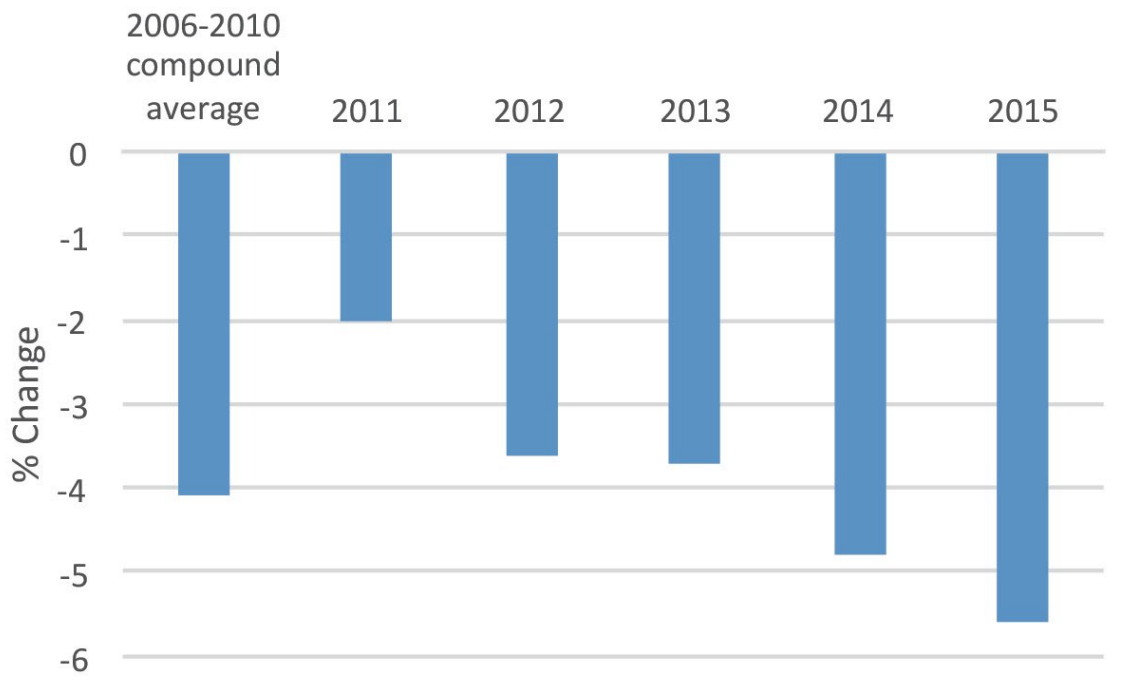

Figure 18.2 Growth rates in Chinese energy intensity of GDP, 2006-15

Sources: Data for 2011-15 from NBS (2016); 2006-10 compound average computed from aggregate 19.1 per cent reduction reported for the period of the Eleventh FYP (see, for example, Lewis 2011). 


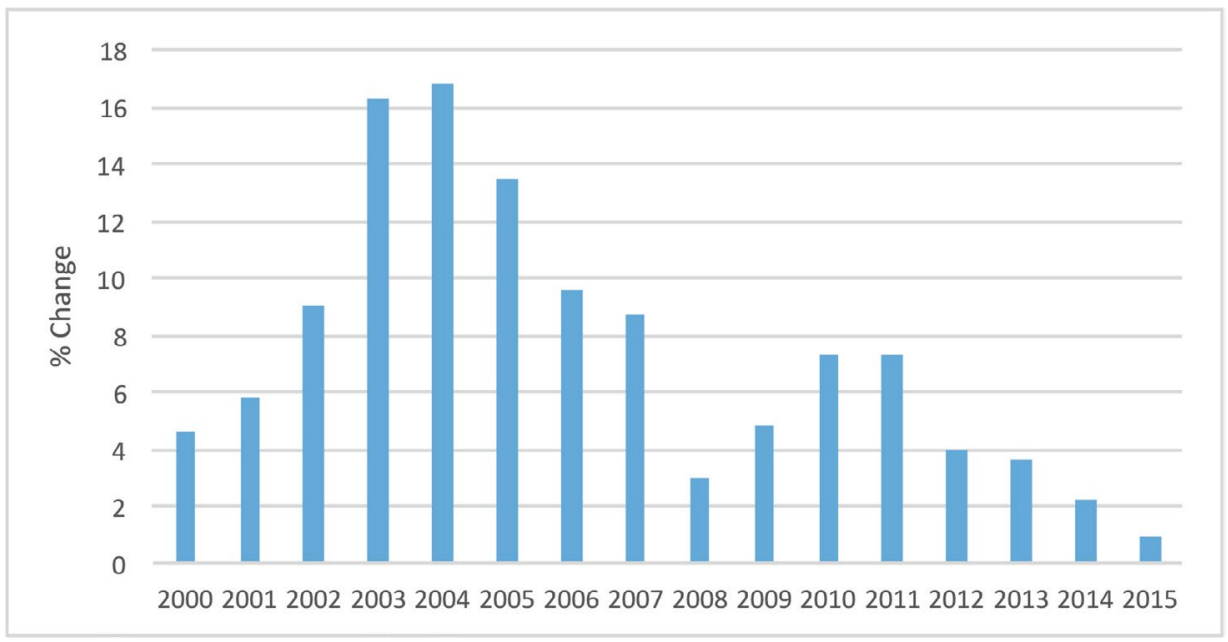

Figure 18.3 Chinese PEC growth rates, 2000-15

Sources: NBS (2015a, 2016).

The data in Figure 18.1 show GDP growth falling from an average of 10.5 per cent per annum over the period 2000-10 to below 7 per cent in 2015 (6.9 per cent, according to official statistics; NBS 2016). ${ }^{2}$ This falling growth rate is explained by the combination of (predominantly structural) factors discussed above, albeit partly offset by faster growth in domestic consumption and tertiary production, which are at the heart of the 'new normal' model (IMF 2015; NBS 2016).

This change in economic structure also helps to explain why the annual decline in the energy intensity of GDP has actually accelerated over the past two years at the same time as GDP growth has slowed (Figure 18.2). Central to understanding this dynamic is the relationship between industry and GDP, given that industry is a very large consumer of energy within China's economy. Under the old growth model, industry ${ }^{3}$ expanded rapidly, ultimately accounting for 44 per cent of GDP in 2013 - an exceptionally high level compared with countries at similar levels of development (Grubb et al. 2015; Xu et al. 2014). As the share of industry in an economy declines relative to the household, commercial and transport sectors, the energy requirement of economic activity tends to fall (Grubb et al. 2015; Schafer 2005). This appears to be what is now happening in China, and this in turn is putting downward pressure on the energy intensity of GDP (Green and

2 Many forecasters using alternative methods think China's growth in 2015 was significantly lower. See, for example, the average of forecasts by experts using alternative methods produced by Consensus Economics (cited in Wolf 2015).

3 Industry here includes 'basic industrial production (e.g. mining and materials production) and manufacturing industry, and the energy and emissions also associated with these sectors' use of electricity' (Grubb et al. 2015: S34). 
Stern 2016). Changes in output from the steel and cement industries, which are especially energy intensive, over the past two years illustrate the scale and speed of the decline in energy-intensive economic activity in China. Whereas steel and cement production grew at a compound average annual rate of more than 15 per cent and 10 per cent, respectively, during the period of heavy industrial growth between 2000 and 2013, output in both sectors contracted in 2015 - crude steel by more than 2 per cent and cement by more than 5 per cent, year-on-year (NBS 2016).

These structural changes affecting the composition of GDP have occurred on top of an ongoing trend of energy efficiency improvement within industries. Beginning with the Eleventh FYP (2006-10), China has introduced and expanded a range of targets and policies to improve energy conservation within industry and other economic sectors (see Song et al. 2015). Macro-level targets to reduce the energy intensity of GDP were primarily intended to guide intra-industry energy conservation efforts. During the Eleventh FYP, energy intensity decreased by 19 per cent relative to the 2005 baseline - just shy of the government's 20 per cent target (Lewis 2011). Energy efficiency efforts were expanded throughout the Twelfth FYP, contributing to that plan's 16 per cent energy intensity reduction target (relative to 2010) being easily beaten-by more than 3 percentage points. ${ }^{4}$

The most important policies for improving energy efficiency have been the 'Top 1,000 Enterprises Energy Conservation Action Program' (later expanded into the 'Top 10,000 Enterprises' program), which provides for energy conservation within energy-intensive state-owned enterprises (SOEs), and the Energy Conservation Law (revised in 2007), which provides a legal basis for the systematic monitoring, evaluation and enforcement of energy conservation performance.

The top enterprises program requires managers of SOEs to achieve targeted energy savings. The main means through which targets are implemented in China's planning system is by subdividing national targets and allocating them to provincial and local officials and to managers of SOEs, who are held accountable for achieving them through a system of performance monitoring and evaluation known as the Target Responsibility System. Crucially, personnel evaluations under this system are tied to job promotion within the Communist Party, meaning officials and SOE managers have strong incentives to achieve their targets. Different targets have different evaluative weights and, historically,

4 As discussed above, these targets also capture changes in the balance of energy-intensive and non-energyintensive activities within overall economic activity, which helped especially to reduce energy intensity during the later stages of the Twelfth FYP (see Figure 18.2). The energy intensity decline across the Twelfth FYP was calculated using data from NBS (2016). 
economic growth targets have been privileged over environmental targets. However, this is gradually changing and, indeed, the National Development and Reform Commission (NDRC) has deemed the abovementioned SOE energy conservation targets essential (or 'veto') targets, meaning failure to achieve them is deemed to result in an automatic failure for the entire performance review (see, for example, State Council 2007). Accordingly, China's energy conservation system has had a strong incentive effect at the industry level, driving improvements in industrial energy efficiency (Zhao and Ortolano 2010). Some evidence of gaming - undetected by inadequate verification processes - has been observed (Zhao et al. 2015). The system of energy conservation targets and associated accountability mechanisms for subnational government officials have been found to have strengthened the institutional arrangements and government capacity for improving energy performance at the local level (Li et al. 2013).

In sum, the combined effect of changes in the growth rate and composition (and hence energy requirements) of economic activity in China and policydriven improvements in energy efficiency within industries has been a dramatic slowdown in the growth of China's total PEC - from a compound annual rate of more than 8 per cent per year between 2000 and 2013 to less than 1 per cent year-on-year in 2015 (Figure 18.3).

\section{The demand-side in the medium term: Trajectory, risks and opportunities}

Looking forward over the next decade or so, how are these factors affecting energy demand likely to evolve? What are the key opportunities and risks? And how could policy respond effectively to these? We first consider GDP growth and the structure of the economy, and then turn to energy efficiency.

It is likely that the recent decline in the overall growth rate in Chinese economic activity marks the beginning of a long-term structural trend (see, for example, IMF 2015; Hu 2015; Johansson et al. 2013; Pettis 2013; Pritchett and Summers 2014). Two key mechanisms (which are related) can be discerned here. The first - to use language popular over the past few years in China-reflects a Lewis turning point, as discussed above, associated with a running down of 'surplus' labour, combined with a slowing of the 'catch-up' growth, which was fuelled by industrial investment, cheap labour and urbanisation (such slowing in growth associated with these processes has been experienced by a number of developing countries) (Das and N'Diaye 2013; Garnaut and Song 2006; Green and Stern forthcoming; Huang and Cai 2014). 
The second has more to do with the dynamics of savings and investment in China. As discussed above, the very high investment share of GDP in China is likely to be unsustainable and there are large debt-related vulnerabilities in China's financial sector. Thus, China's investment rate is likely to fall significantly, one way or another, over the next decade (Pettis 2013); there will be a rise in the consumption share, especially of services. Because it is likely, as reflected in the experience of other countries, to be more difficult to obtain very high growth rates from consumption expansion and productivity improvements, compared with the past strong driver of investment in capital stock, this structural transition will entail slower GDP growth for China (though it would significantly improve living standards) (Green and Stern 2016).

In addition to affecting the rate of growth, this structural transition will continue to reduce the energy requirements of China's economic activity in the manner discussed above (Green and Stern 2016). While relative growth in the household, transport and commercial sectors will increase the energy demand from these sectors, such increases are for the foreseeable future likely to be strongly outweighed by the decline in energy demand associated with the shift away from industry, which we expect to continue (Grubb et al. 2015). In particular, we expect to see further declines in heavy industry sectors, with excess capacity such as steel and cement, especially in the near term, as the government prioritises 'supply-side policy' and 'capacity management', and as production in these sectors is restructured and rationalised during the Thirteenth FYP (regarding steel, see, for example, Bloomberg News 2016a, 2016c).

A smooth and successful transition to China's new economic model is far from guaranteed. Success will depend on increasing domestic consumption and on greatly improving productivity - especially of capital - as investment rates fall (Stern 2011; Green and Stern forthcoming). Moreover, obtaining these outcomes will require domestic policy reforms, which will entail transitional costs and political-economic challenges in declining sectors and affected regions (see, for example, Green and Stern 2014, 2016). The alternative to successful transition to the new model is not 'continuation of the old model', as this is effectively impossible (at least in any sustainable sense over the medium to long term) and surely undesirable, for the reasons presented earlier. The unfortunate alternative potential outcome associated with trying to avoid the new model (or something similar) is a sharper decline in growth followed by stagnation (for discussion, see Pettis 2013). Although a degree of stimulus directed towards the drivers of the old model of growth could boost GDP growth of the energy-intensive kind in the short term, it would do so at the cost of sustainable growth in the longer term, as it would undermine much needed efforts towards policy reform, productivity improvement and sustainable debt management (IMF 2015; Green and Stern 2016). 
There are much better ways than credit-fuelled stimulus of the construction and heavy industry sectors for China to maintain strong aggregate demand and low unemployment through the transition to the new model. One is to increase per capita government spending on provision of social services (education, health care, pensions, welfare support) and to expand coverage to the full resident populations of cities (not merely registered residents). Second, the government could expand specific forms of transitional social protection-such as job retraining and structural adjustment assistance - to facilitate structural change, equip workers with skills in growing economic sectors and reduce the financial impact of transition, especially on workers and affected communities. A third response is to incentivise a redirection in investment towards decarbonisation of the economy, environmental clean-up, pollution reduction and energy and resource efficiency (see further Green and Stern forthcoming). Each of these areas does indeed feature strongly in the Thirteenth FYP. While many of these (education, skills, environmental services and so on) might be classified as consumption (public or private) in conventional terms of accounting, they could - and, in our view, should - be seen as investments in human and natural capital.

The future rate of decline in energy intensity depends also on continued improvements in energy efficiency - that is, within industries. There are several reasons recent improvements are likely to continue at (at least) a similar rate to those of recent years: China remains far from the energy efficiency frontier (Baeumler et al. 2012; Hove et al. 2015); the energy efficiency frontier is likely to expand rapidly in the next decade as countries increasingly decarbonise their energy sectors; energy conservation policy, which yields multiple economic, environmental, social and geopolitical benefits, remains a key policy focus for government, as evidenced in the Thirteenth $\mathrm{FYP}^{5}{ }^{5}$ and China has relatively successful systems and policies in place to incentivise and monitor energy conservation improvements (as discussed above), which can be strengthened and built on.

Against this must be weighed a number of risks on the energy efficiency front. One is that energy efficiency improvements slow within the heavy industries experiencing structural stagnation or decline. Another is that the fast-growing household and commercial sectors will lead to rapid growth in energy demand for vehicles, buildings and appliances. In each of these cases, there is a critical role for policy - from factor pricing to regulated standards and from urban planning to government procurement - to ensure or encourage high and continuously improving standards of efficiency in new capital stock (for example, buildings,

5 For example, the 'use of energy and resources more efficiently' is a key component under the 'Promoting green, circular, and low-carbon development' major task of the plan. 
vehicles and appliances) and the efficient retrofitting of existing building stock and industrial facilities (Green and Stern 2014; Hove et al. 2015; World Bank and DRC 2014).

Overall, in light of forecast slower growth, the changing structure of economic activity and continued energy efficiency improvements, we anticipate only modest growth in China's PEC over the next decade - of less than 2 per cent per annum, based on what are arguably conservative assumptions across each of these dimensions (see Green and Stern 2016: Section 4). Being less conservative, one can see how a continuation of patterns from 2014-15 could lead to a scenario in which GDP growth averages 5-6 per cent and annual reductions in energy intensity also average 5-6 per cent over the next decade. Under this scenario, the range of PEC growth could be centred on zero. This would imply that every tonne of carbon dioxide per unit of energy saved on the supply side would translate into an equivalent absolute reduction in carbon dioxide.

\section{The supply side: Beyond peak coal}

We now turn to analysing policies and trends on the energy supply side. We begin by looking at measures relating to the diversification of China's energy supply and at the outcomes that have been achieved in terms of the energy production and electricity generation mix. We then consider China's main targets and policies aimed at reducing GHG emissions per se. Finally, we consider the outlook on the energy supply side over the decade ahead and discuss some potential issues and challenges.

\section{Diversification of China's energy supply: Motivations, measures and outcomes}

Coal has long been the dominant source of energy consumed in China, accounting for around two-thirds of PEC in 2014 (NBS 2015a). Between 2000 and 2013, Chinese coal consumption grew at a compound average rate of more than 8 per cent per year (NBS 2015a). By the end of that period, China was consuming half of the coal consumed in the entire world.

Over the past decade or so, China has for various reasons increasingly sought to diversify its energy supply (Boyd 2012). The first motivation is energy security. After China's energy consumption increased dramatically in the first half of the 2000s (during which time the energy intensity of GDP actually increased for a brief period), energy security became a more important issue for Chinese policymakers (Baghat 2010; Boyd 2012). As China became increasingly dependent on imported fossil fuels in the subsequent decade - for example, China is a large 
importer of oil and gas, and it became a net coal importer in 2009-it became increasingly exposed to international energy prices. This exposure poses not only geopolitical risks for China, but also economic risks:

Compared to developed economies, China's economy is more exposed to price volatility in the global energy market due to its fossil fuel dominated energy structure and high proportion of secondary industry. Sectors of the economy with high exposure to price risk account for about 20\% of GDP, several times higher than that in the developed economies. (Global Commission on the Economy and Climate 2014, p. 1)

Accordingly, energy security has remained high on the government's policy agenda.

A second motivating factor behind China's energy supply diversification is the strategic development of innovation-oriented manufacturing industries in renewable and nuclear energy, for which considerable government support has been provided. During the 2000s, China began strongly supporting the development of its wind (Dai et al. 2014; Wang et al. 2012), solar photovoltaics (Zhang et al. 2014) and nuclear (World Nuclear Association 2016) industries. While there have been ups and downs, China has had considerable success in developing internationally competitive companies with innovative capabilities in these industries (Nahm and Steinfeld 2014). As noted earlier, as China transitions to its new growth model, it needs, and indeed aspires, to rely more on productivity improvements, innovation and higher value-added sectors for its industrial growth. In this context, it has identified low/zero-carbon electricity generation, advanced electricity grid infrastructure and clean transportation industries (including the energy efficiency technologies and services sector and 'new energy vehicles', among others) as key sources of future industrial growth and has targeted these for ongoing state support (Xinhua 2015; ERI 2015; Nahm and Steinfeld 2014; Ng et al. 2016).

A third motivation for diversifying the energy supply-and one that has increased rapidly in salience since the latter part of the previous decade- - has been to combat China's worsening levels of air pollution, especially in its coastal megacities (Sheehan et al. 2014). A fourth motivation for diversification is to contribute to the mitigation of climate change (Boyd 2012).

These diverse motivations have resulted in a complex web of targets, policies and state investments (for simplicity, we will refer to these collectively as 'measures') aimed at diversifying China's energy supply away from coal.

These include, first, various measures aimed at expanding the supply of 'nonfossil' (renewable and nuclear) power generation and expanding the supply of natural gas in power generation, industry and buildings. The government has 
set overall targets for the non-fossil fuel share of PEC of 15 per cent by 2020 and 20 per cent by 2030, as well as absolute capacity targets for individual energy sources. It has also introduced various support mechanisms to encourage wind and solar power production, ${ }^{6}$ nuclear energy ${ }^{7}$ and innovation in each of these areas (Andrews-Speed 2012). As the electricity mix has diversified towards increasing amounts of variable (wind and solar) and invariable (nuclear) generation in more diverse geographic locations - and in anticipation of future such expansions - the government has also encouraged the expansion of highvoltage electricity transmission networks and the development of energy storage (especially pumped hydro sites and a battery storage industry) (Garnaut 2014; Mathews and Tan 2014).

As air pollution reduction has become a more urgent priority in recent years, government energy policy has increasingly expanded beyond attempts to increase the relative shares and absolute levels of non-coal energy sources to encompass direct controls on coal production and consumption (Sheehan et al. 2014). For example, in 2013, pursuant to its Air Pollution Prevention and Control Plan (State Council 2013), the government established coal caps in nine provinces and cities that together account for 30 per cent of China's coal consumption (Song et al. 2015). In the key economic regions that are heavily affected by air pollution - Beijing-Tianjin-Hebei, Yangtze River Delta and Pearl River Deltathe plan prohibits the building of new coal-fired power plants and seeks to remove some heavy industry from these regions. This set of measures extends well beyond longer-standing (and ongoing) measures to improve the efficiency of China's coal-fired power generation fleet by replacing the least-efficient and highest-polluting plants with larger and more efficient ones (Mai and Feng 2013).

Efforts to reduce coal consumption in industry, which accounts for about half of China's total coal consumption, are also under way. The downward pressure on industrial coal use resulting from falling steel and cement output (discussed above) is being compounded by trends within these industries to substitute away from emissions-intensive production processes, such as by using electric arc furnaces using recycled scrap steel. ${ }^{8}$

The results of all these and other measures can be measured partly in terms of expansion in non-coal energy capacity (see Figure 18.4). For example, China installed a record-breaking amount of wind and solar power in 2015 (more than $30 \mathrm{GW}$ and $18 \mathrm{GW}$, respectively), as well as $18 \mathrm{GW}$ of hydro-electric and $6 \mathrm{GW}$ of nuclear power.

6 These include, for example, the Renewable Energy Law (introduced in 2005 and subsequently amended), feed-in tariffs for distributed solar rooftop installations and provincial renewable energy deployment quotas (Chu 2015).

7 Including setting wholesale prices (World Nuclear Association 2016).

8 Ross Garnaut (Personal communication, 12 March 2015). 


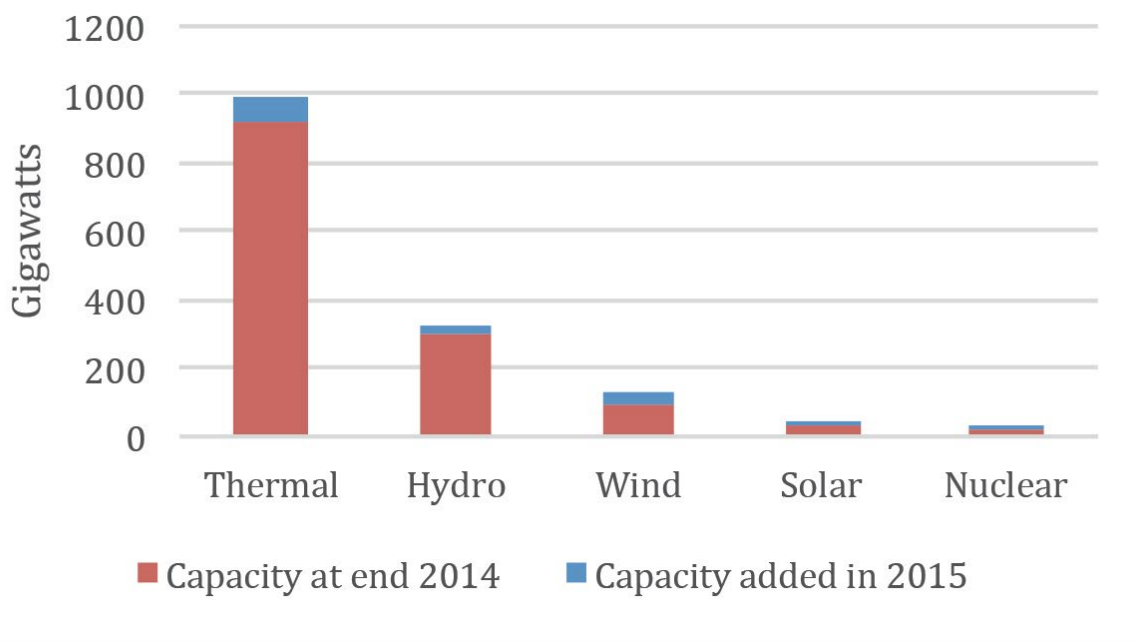

Figure 18.4 Electricity generation capacity in China by source

Sources: Data for 2015 total capacity from NBS (2016); capacity additions in 2015 inferred from difference between NBS (2016) data and 2014 data from China Electricity Council (2015); 'thermal' category includes coal, gas, biomass, cogeneration and wastes and is not disaggregated in Chinese statistics; the 'total' figure is as reported in NBS (2016) and is, for reasons that are not clarified, greater than the sum of the components also reported therein.

The non-coal energy capacity expansions of recent years have also contributed greatly to changes in China's electricity generation mix, such that coal-fired power generation has fallen for the past two years as generation from other sources has expanded (see Green and Stern 2015; NBS 2016; Plumer 2016). These shifts in the electricity market, along with changes in industrial energy consumption, add up to a profound change in China's overall energy supply mix (Figure 18.5).

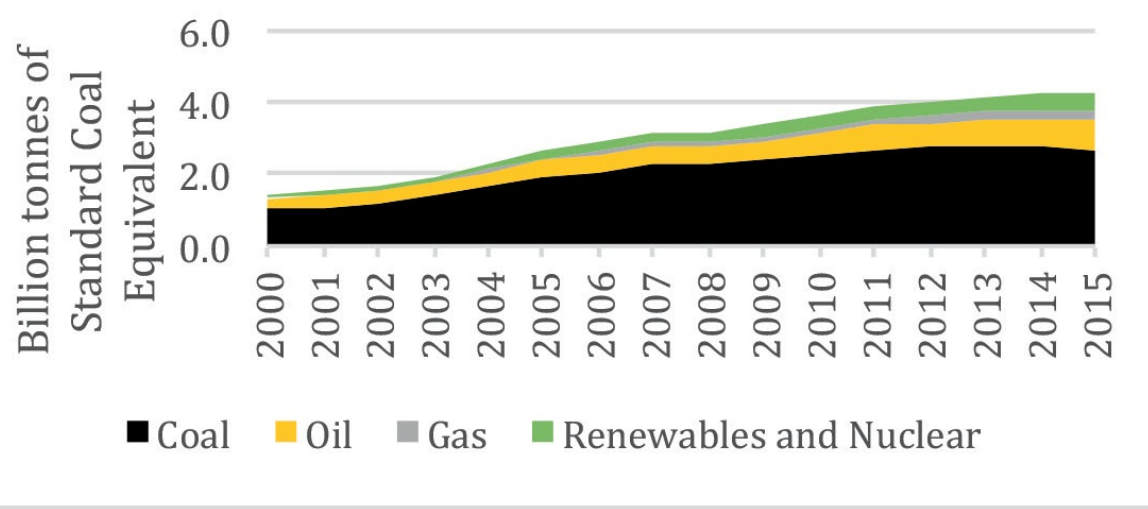

Figure 18.5 Total PEC by source

Sources: NBS (2015a, 2016). 
In 2014-15, these changes in the energy supply mix combined with the dramatic slowdown in energy demand growth to cause a remarkable turnaround in China's coal consumption (see Figure 18.5). Measured in terms of energy content, China's coal consumption was flat in $2014^{9}$ (NBS 2015a; EIA 2015) ${ }^{10}$ and in 2015 it fell by more than 3 per cent, according to preliminary estimates (NBS 2016). After compound annual growth in coal consumption of more than 8 per cent per year between 2000 and 2013, this turnaround is remarkable. The rapid change is also reflected in coal production and import data for 2014 and 2015; coal production fell 2.5 per cent in 2014 and a further 3.3 per cent in 2015, and coal imports fell 10.9 per cent in 2014 and 29.9 per cent in 2015 (NBS 2015b, 2016). Because the decline in China's coal consumption is caused by a combination of forces on the demand and supply sides that are overwhelmingly structural, it is likely, in our view, that China will never again consume as much coal as it did in 2013-14. In other words, history will likely show that 2013-14 marked the peak in Chinese coal consumption. ${ }^{11}$

\section{Measures to reduce GHG emissions per se}

All of the strategies, policies and other changes discussed so far affect GHG emissions in a more or less indirect way, through their effect on energy-intensive economic activity or the energy supply mix. In addition, China has introduced a number of measures aimed at reducing GHG emissions per se. We focus here on two such measures: China's targets for reducing the carbon dioxide intensity of GDP and the associated governance arrangements, and carbon emissions trading.

9 When measured in terms of physical tonnage, coal consumption fell by 2 per cent in 2014 (EIA 2015). The difference between the energy content (standard coal equivalent, SCE) and physical tonnage measurements reflects the increase in the average quality (hence energy content) of coal burned in China in 2014. Preliminary statistics from China's National Bureau of Statistics (NBS 2015b) had earlier estimated a 2.9 per cent decline in coal consumption in SCE terms in 2014, before changes in average energy content were factored in.

10 China's National Bureau of Statistics (NBS 2015a) reported an increase of less than 0.06 per cent in the consumption of coal in SCE terms in 2014 compared with 2013. The figures cited here take into account the upward revisions to China's historical coal consumption made by China's statistical agencies following the five-year economic census, which took place in 2013. The census put China's coal data on a surer footing.

11 While there has been considerable attention paid to anomalies and revisions in China's recent historical coal data up to the end of 2013 (Buckley 2015; Wilson 2015; Wynn 2015), the 2014 and 2015 data are likely to be relatively accurate owing to changes in calculation methods made following China's five-year economics census in 2013. The 2014-15 data, moreover, are consistent with wider market trends, most relevantly in thermal electricity generation (for which data are more reliable due to metering) and in heavy industry sectors such as steel and cement, discussed above (see China Shenhua Energy Company Limited 2015: 14-15; Green and Stern 2015). Accordingly, it is highly unlikely that the 2014-15 coal data misrepresent the general picture over this period: flattening and then falling coal consumption, production and imports. 
China has, since its Twelfth FYP (2011-15), adopted targets to reduce the carbon dioxide intensity of GDP, expressed against a 2005 baseline. The targets initially set were to achieve a 17 per cent reduction by 2015 - which it has achievedand a 40-45 per cent reduction by $2020 .{ }^{12}$ The Thirteenth FYP includes a target of reducing the carbon dioxide intensity of GDP by 18 per cent over the course of the plan - that is, by 2020 - compared with 2015 levels. This equates to a 50 per cent reduction on 2005 levels, implying a strengthening of the 2020 target compared with the original 40-45 per cent target, a recognition that China will likely 'far surpass' the latter target (Xie, quoted in King 2016). ${ }^{13}$

China's carbon dioxide intensity reductions have occurred largely because of the economic factors and policy measures already discussed in this chapter. Relatively little progress has been made in developing robust systems for incentivising subnational governments and SOEs to reduce carbon dioxide intensity per se, especially when compared with the efforts that have gone into energy conservation and non-coal energy expansion. Determining the achievement of carbon dioxide intensity targets at the micro level requires not only granular data on economic activity but also a detailed system for the monitoring, reporting and verification (MRV) of carbon dioxide emissions at a scale relevant to the performance evaluation-for example, at a provincial scale for provincial officials and at a facility and enterprise scale for enterprises. Establishing such systems is a major task in any country; it is enormous in a country as large and administratively complex as China. While ongoing efforts are being undertaken to improve carbon dioxide MRV mechanisms, comprehensive systems are still lacking. For example, despite the inclusion of the carbon dioxide intensity target in the Twelfth FYP, it was not until August 2014 that the NDRC released the implementation plan for the evaluation of performance against this target. Many provinces have not implemented provincial versions of the Implementation Plan and, as of 2015, the NDRC had not done any formal assessment of progress made by provinces in achieving targets.

Robust facility-level and enterprise-level MRV systems for GHGs are but one of many institutional prerequisites for an effective carbon emissions trading scheme (ETS), ${ }^{14}$ which is the other key measure China has introduced to mitigate GHG emissions per se.

12 Aggregate carbon dioxide emissions can be inferred from economic activity and energy data, without the need for facility and enterprise-level carbon dioxide data.

13 However, on our forecasts, even the strengthened target is likely to be beaten (Green and Stern 2016: Section 4).

14 Such systems are necessary to determine the annual emissions produced by a facility or enterprise, and hence determine the liability of the facility operator or enterprise owner to acquire (and, at the end of a compliance period, surrender to the relevant regulator) carbon permits in respect of their emissions. 
Seven Chinese pilot ETSs - covering two provinces and five major cities - were established during 2013-15. By design, the features of the schemes vary (as do the economic characteristics of the regions themselves). The schemes were established as policy experiments to generate useful lessons and build capacity on the basis of which a national ETS could be developed during the Thirteenth FYP (Zhang 2015).

Ex ante analyses of the expected barriers to effective ETS operation in China (Baron et al. 2012; Jiang 2013; Kong and Freeman 2013; Lo 2013; Lo and Howes 2014; Shen 2013; Teng et al. 2014; Zhang et al. 2014), early ex post facto analyses of the operation of the pilot schemes (Jotzo and Löschel 2014; Lo 2015; Yu and Lo 2015; Shen 2014; Zhang 2015) and expert survey data (de Boer et al. 2015) identify a wide range of major challenges and barriers to the effective development and implementation of such schemes in China. These barriers and challenges include technical complexities concerning issues of institutional design, such as transparent, specific and comprehensive legal provisions for cap-setting, allowance allocation, MRV, liability and enforcement; technical and organisational matters such as the establishment of robust emissions measurement and reporting systems, registries and exchanges and regulatory agencies for market oversight; institutional and political challenges concerning complementary electricity market reform; incongruent cultures and incentive structures among the relevant business sectors; excessive state intervention in market operations; and incomplete regulatory institutions.

Notwithstanding these barriers and challenges, China's Thirteenth FYP confirms that a national ETS will be established, including the release of regulations and oversight systems, and will build on the current pilot schemes (Reklev 2016a). At the time of writing, key officials had foreshadowed the start of the national ETS in the second half of 2017 (Reklev 2016b). The provinces and regions will reportedly be allocated individual intensity targets that add up to the national 18 per cent carbon dioxide intensity reduction goal, and these provincial targets will then be allocated to industries in covered sectors, which include petrochemicals, chemicals, building materials, iron and steel, nonferrous metals, paper production, electricity generation and aviation (Reklev 2016a). The government's preference appears to be to determine allocations on the basis of sectoral emissions intensity benchmarks, so as to mitigate the risk of overallocation that comes with allocations based on absolute emissions targets (Reklev 2016b).

The barriers and challenges identified above - many of which have afflicted ETS experiments in advanced developed countries - will likely constrain the contribution that China's planned national ETS will be able to make to its wider climate mitigation effort for the foreseeable future. The rollout of the national ETS scheme may well benefit that wider effort indirectly, just as the 
pilot schemes have likely done (see Kong and Freeman 2013), including through capacity building, improvement of MRV systems and increased awareness of mitigation opportunities and strategies among Chinese firms and government officials. More substantively, structuring the scheme to focus on intra-industry carbon intensity improvements (as appears to be the preferred direction) may help with ongoing efforts to improve energy efficiency within heavy industries during an expected difficult period for such industries (Green and Stern 2016). Nonetheless, the barriers and challenges to the MRV and trading of carbon dioxide emissions suggest that other new supply-side measures may be worth considering as means to achieve rapid climate change mitigation. We have argued in the past that a combination of direct regulation and upstream taxation of fossil fuels, especially coal, would likely be relatively effective and efficient in the Chinese context (Green and Stern 2014, 2015).

In sum, despite the intense interest of the international climate policy community in China's carbon dioxide intensity targets and nascent carbon trading schemes, these measures have in fact played very little role in the radical shift in China's emissions trajectory that has occurred over the past few years (Green and Stern 2016). Moreover, while the importance of these measures is likely to grow over the next decade, we nonetheless think that they will remain less important than the other factors we discuss in this chapter, on both the demand side (discussed earlier) and the supply side. We now turn to the main drivers on the supply side over this future period.

\section{Energy supply over the medium term: Transformation without growth?}

Over the next decade, we expect continued transformation of China's energy supply, albeit with much uncertainty about the pace of change. We focus here on the electricity and transport sectors.

As discussed earlier, we forecast relatively flat demand for electricity over the next decade. This will create a new dynamic: whereas previously China's investments in non-coal capacity have supplied incremental demand, now new supply will be competing for dispatch in a relatively static market, intensifying competition for market share.

On the one hand, we expect China's expansion of non-coal and non-fossil fuel electricity generation capacity to continue apace, driven by the same motivations identified earlier: energy security, air pollution reduction, industrial modernisation and climate change mitigation. 'Greening' is a central theme of the Thirteenth FYP, which encompasses support for new energy industries, green cities, green finance, modern energy systems, clean energy 
innovation and controlling GHG emissions. In this context, and as more detailed plans and policies for the energy sector over the coming period are developed, we expect state support for financing, manufacturing, deploying, researching and developing zero-emissions electricity generation sources and associated infrastructure and technologies (for example, grid infrastructure and energy storage) to be prioritised and strengthened (see also PBC and UNEP 2015; Kuijs 2015).

Moreover, China's technology-specific absolute targets for capacity expansion in renewable energy have been consistently revised upwards by energy planning agencies as costs have plummeted and the industries have grown (Jiang 2014; Reed 2015). We expect these trends to continue as China and the world move increasingly decisively away from fossil fuels, resulting in the achievement, and possibly raising, of targets for solar and wind energy (currently 150-200 GW and $250 \mathrm{GW}$, respectively). Hydro-electric capacity is likely to expand over the next five years, though constraints on appropriate sites are likely to limit expansion beyond that time. China's highly ambitious targets for nuclear energy and gas may not be met, yet we still expect large build-outs of nuclear and gas-fired electricity capacity (for more detailed discussion, see Green and Stern 2015: 36-39; World Nuclear Association 2016). The continued expansion of non-coal energy infrastructure plays to China's institutional strengths in engineering, manufacturing and mobilising infrastructure finance, and its strong track record in this area provides reasons for optimism about future potential. Favourable international market, technology and financing trends in the renewable energy sector, buoyed by the recent Paris Agreement, should complement China's expansion.

On the other hand, ensuring that China's growing zero-carbon and low-carbon electricity sources are able to achieve their full potential for reducing the carbon intensity of electricity generation will require China to overcome a number of institutional and political hurdles that are likely to prove more challenging. A key set of institutional reform priorities involves marketisation and pricing reforms in the electricity sector. Fossil fuel production and electricity production currently enjoy a range of subsidies and are pervasively undertaxed (CCICED 2014), putting renewable energy in particular at a competitive disadvantage. A key priority is to remove subsidies for, and increase taxes on, fossil fuels, especially coal, so that prices for these pollution-intensive commodities more closely reflect their full social costs. ${ }^{15}$ Additionally, reforms to the electricity sector are needed to ensure that prices paid by consumers and to generators fully reflect these social costs and to ensure therefore that the lowest-carbon,

15 We have advocated a rising coal tax as a highly efficient and administratively effective measure that would be well suited to China's institutional context (Green and Stern 2014, 2015; see also CCICED 2014). 
lowest-pollution sources of generation are given priority in electricity dispatch arrangements (so-called green dispatch). At an administrative level, these reforms are likely to be technically challenging in a country that has had limited experience of effective externality taxation and market-based regulation.

The political challenges of enacting and implementing these reforms are likely also to be formidable. In a flat market for electricity, altering pricing and dispatch arrangements to favour zero-carbon and low-carbon energy sources will mean that the existing coal-fired power generation fleet will see its annual hours of operation continually falling in absolute terms (as has already happened over the past two years). In fact, individual coal-fired generators would see their generating hours fall even more precipitously: the continuing wasteful expansion in coal-fired generation capacity means that the coal fleet will be expanding at the same time as its share of a flat electricity market is falling (Myllyvirta et al. 2015; Spencer 2016). These trends are likely to intensify ongoing conflict among generators and system operators over dispatch priority (which determines which generators get paid) - conflicts that in 2014-15 led to high rates of wind and solar 'curtailment' and more coal than necessary being consumed (The Economist 2014).

Ultimately, transforming an electricity sector that has great overcapacity and not growing substantially (and possibly not growing at all or even shrinking) will be a complex political-economic task that requires managing the decline of an entire industry associated with coal. That will involve stranding assets on a large scale, leaving millions of people in need of alternative employment and, in some communities, removing the main source of economic activity (this applies not only to coal industries, but also to steel, cement and other heavy industries that were central to the old model of growth). Managing this 'degrowth' aspect of China's energy transformation will require a proactive strategy from the government across each of these dimensions. Encouragingly, the Central Government has given strong indications in this direction. 'Supply-side reform' and reducing overcapacity are key themes of the Thirteenth FYP. In the coal and steel industries specifically, the government has announced targets to close large amounts of excess production capacity, imposed a three-year moratorium on new coalmine approvals and set up funds to support coal and steel industry restructuring and the redeployment of millions of coal and steel workers (Bloomberg News 2016b, 2016c). Monitoring - and indeed supporting - this essential transition should be a major focus of the international research and policy communities in the years ahead.

Turning to the transport sector, the outlook for China is perhaps more uncertain. On the one hand, slowing GDP growth and heavy industrial activity will continue to put downward pressure on oil demand, as they did in 2014-15, to the point that diesel fuel consumption decreased in 2015 (Olson and Spegele 2016). 
On the other hand, oil consumption growth will be driven by rising demand from household and commercial transportation as these sectors grow, consistent with the shift to the new growth model. Yet projections of the future vehicle stock vary enormously (see Gambhir et al. 2015). The low global oil price will likely increase oil demand, though the government has moved to impose a price floor on crude oil of US $\$ 40$ a barrel, which will be reflected in petrol prices, mitigating the consumer demand response (Bloomberg News 2016a). There are also many supply-side variables that complicate forecasting, including the potential for disruptive technological innovation in 'new energy vehicles' such as electric, hybrid and autonomous vehicles - a market that China is itself already building through supportive policy, and which it has made a strong focus of the Thirteenth FYP (Ng et al. 2016).

On balance, it seems most likely that oil demand will grow over the coming decade in China, albeit more slowly than over the previous decade, and more slowly than has been projected by major international forecasters in recent years (see Coulter 2015; Olson and Spegele 2016).

Overall, it appears likely that the transformation of China's energy sector will continue and strengthen over the next decade. We expect coal to continue to decline in absolute terms and as a share of PEC, renewable energy to grow rapidly, nuclear and gas to grow steadily and oil to grow moderately.

\section{Conclusion}

From this analysis of economic and policy factors on the demand and supply sides of China's energy transition, we conclude that China's net emissions over the next decade will grow only very slowly - and will peak sometime during this period (for an illustrative scenario, see Green and Stern 2016: Section 4). It is not beyond the realm of possible outcomes that carbon dioxide emissions, which appear to have fallen in 2015 (Boren 2016; Peters and Korsbakken, cited in Plumer 2016), will continue to fall gradually over this period, which would imply that 2014 was China's peak year for carbon dioxide emissions. The actual scenario will depend on the extent to which risks such as those discussed in this chapter arise and can be effectively mitigated.

Ultimately, whatever the exact trajectory turns out to be, it is clear that the outlook for China's carbon dioxide emissions has changed radically over the past few years. This is welcome news for the global effort to mitigate climate change. If China's emissions were to continue rising at rates similar to those of the first decade of this century, it would make it extremely difficult for global warming to be restrained to less than $2{ }^{\circ} \mathrm{C}$ above pre-industrial levels - the conventionally agreed global climate mitigation goal (Boyd et al. 2015; Green and 
Stern 2015: 14-18). The emerging outlook for China's emissions trajectory, in contrast, suggests that a mitigation pathway of less than $2^{\circ} \mathrm{C}$ is more feasible than previously expected.

The analysis presented in this chapter also has implications for China's international climate change diplomacy, and for global climate policy more generally. China played a crucial role in the successful negotiation of a new international climate change agreement in Paris in December 2015. The Chinese Government's general attitude and approach to global climate change mitigation during the Paris process were flexible and constructive, and its own specific policy pledges, including to peak its carbon dioxide emissions by 2030, were more stringent than in past negotiations. The analysis presented here sheds light on the domestic, structural drivers of this constructive turn in China's international climate diplomacy. The domestic economic and policy trends we have identified gave the government confidence that the country could achieve its pledged targets and that major steps by other countries to decarbonise the world economy would align with China's short- to medium-term economic interests, not just its long-term interest in avoiding catastrophic climate change.

In fact, if the analysis in this chapter is correct, China's official target to peak its carbon dioxide emissions by 2030 is likely to be substantially beaten, as are its other 2030 targets for non-fossil fuel energy and carbon dioxide intensity of GDP (see also Green and Stern 2016: Section 4). This probability highlights the virtue of the 'dynamic' climate governance model embodied in the Paris Agreement, whereby countries are required to update their pledges with more ambitious targets and policies over time. China is likely to be in a strong position to strengthen its commitment ahead of the first five-year revision period in 2020.

Achieving the ultimate, long-term objective of the Paris Agreement with a reasonable probability will require all countries, including China, to reduce their emissions rapidly towards net zero global emissions within the second half of this century. The challenge for China now is therefore one of avoiding a 'long plateau' in emissions by implementing reforms that will enable it simultaneously to achieve growing prosperity and rapidly falling emissions after the carbon dioxide peak (whenever it occurs). Given the various social, environmental, economic and financial reasons China has for moving rapidly to a clean, low-carbon, less resource-intensive, services-oriented economyquite independently of mitigating climate change - these objectives are highly complementary. 


\section{References}

Andrews-Speed, P. (2012), The governance of energy in China: Transition to a lowcarbon economy, Basingstoke, UK: Palgrave Macmillan.

Baeumler, A., Ijjasz-Vasquez, E. and Mehndiratta S. (eds) (2012), Sustainable low-carbon city development in China, Washington, DC: The World Bank.

Baghat, G. (2010), China's energy security: Challenges and opportunities, The Journal of Social, Political, and Economic Studies, 35: 137-166. Available from: jspes.org/online.html.

Baron, R., Aasrud, A., Sinton, J., Campbell, N., Jiang, K. and Zhuang, X. (2012), Policy options for low-carbon power generation in China, Paris: OECD \& IEA.

Bloomberg News (2016a), Crude stopped falling at $\$ 40$ a barrel for Chinese consumers, Bloomberg News, 18 January. Available from: bloomberg.com/ news/articles/2016-01-18/oil-prices-stopped-falling-at-40-a-barrel-forchinese-consumers.

Bloomberg News (2016b), China puts coal production capacity on chopping block, Bloomberg News, 5 February. Available from: bloomberg.com/ news/articles/2016-02-05/china-puts-1-billion-tons-of-coal-capacity-onchopping-block.

Bloomberg News (2016c), China expects 1.8 million coal, steel layoffs on capacity cuts, Bloomberg News, 29 February. Available from: bloomberg. com/news/articles/2016-02-29/china-expects-1-8-million-coal-steel-layoffson-capacity-cuts.

Boren, Z. D. (2016), China's fossil fuel emissions fall for the second year running, Energy Desk, 29 February. Available from: energydesk.greenpeace. org/2016/02/29/china-coal-fall-the-sequel/.

Boyd, O. (2012), China's energy reform and climate policy: The ideas motivating change, Centre for Climate Economics and Policy Working Paper 1205, Canberra: The Australian National University.

Boyd, R., Stern, N. and Ward, B. (2015), What will global annual emissions of greenhouse gases be in 2030, and will they be consistent with avoiding global warming of more than $2^{\circ} \mathrm{C}$ ?, Policy Paper, London: Grantham Research Institute on Climate Change and the Environment and Centre for Climate Change Economics and Policy. Available from: lse.ac.uk/GranthamInstitute/ publication/what-will-global-annual-emissions-of-greenhouse-gases-be-in2030-and-will-they-be-consistent-with-avoiding-global-warming-of-morethan-2c/. 
Buckley, C. (2015), China burns much more coal than reported, complicating climate talks, The New York Times, 3 November. Available from: nytimes. com/2015/11/04/world/asia/china-burns-much-more-coal-than-reportedcomplicating-climate-talks.html?_r=0.

Central Committee of the Communist Party of China (CCCP) (2013), Decision on major issues concerning comprehensively deepening reforms, 15 November, Beijing: CCCP. Available from: news.xinhuanet.com/politics/201311/15/c_118164235.htm. English version available from: english.people. com.cn/90785/8525422.html.

China Council for International Cooperation on Environment and Development (CCICED) (2014), Evaluation and prospects for a green transition process in China, CCICED Task Force Report, Beijing: CCICED. Available from: cciced. net/encciced/policyresearch/report/201504/P020150413497198320874.pdf.

China Electricity Council (2015), China power industry situation and prospects, 10 March, Beijing: China Electricity Council. Available from: cec.org.cn/ yaowenkuaidi/2015-03-10/134972.html.

China Shenhua Energy Company Limited (2015), Third quarterly report for the year 2015, Beijing: China Shenhua Energy Company Limited. Available from: iis.quamnet.com/media/IRAnnouncement/1088/EN_US/002345329-0.PDF.

Chu, J. (2015), RE 100: China's fast track to a renewable future, Beijing: The Climate Group. Available from: theclimategroup.org/_assets/files/RE100China-analysis.pdf.

Coulter, T. (2015), China's fuel demand to peak sooner than oil giants expect, Bloomberg News, 1 April. Available from: bloomberg.com/news/ articles/2015-04-01/china-s-fuel-demand-to-peak-sooner-than-oil-giantsexpect.

Dai, Y., Zhou, Y., Xia, D., Ding, M. and Xue, L. (2014), The innovation path of the Chinese wind power industry, Bonn: German Development Institute/ Deutsches Institut für Entwicklungspolitik. Available from: die-gdi.de/ discussion-paper/article/the-innovation-path-of-the-chinese-wind-powerindustry/.

Das, M. and N'Diaye, P. (2013), Chronicle of a decline foretold: Has China reached the Lewis turning point?, IMF Working Paper 13/26, Washington, DC: International Monetary Fund. Available from: imf.org/external/pubs/ft/ wp/2013/wp1326.pdf.

de Boer, D., Roldao, R. and Slater, H. (2015), 2015 China carbon pricing survey, Beijing: China Carbon Forum. Available from: chinacarbon.info/wp-content/ uploads/2015/09/2015-China-Carbon-Pricing-Survey-EN.pdf. 
Energy Information Administration (EIA) (2015), Recent statistical revisions suggest higher historical coal consumption in China, Washington, DC: Energy Information Administration. Available from: eia.gov/todayinenergy/detail. $\mathrm{cfm} ? \mathrm{id}=22952$.

Energy Research Institute (ERI) (2015), China 2050 high renewable energy penetration scenario and roadmap study: Executive summary, April, Beijing: National Development and Reform Commission. Available from: efchina.org/ Attachments/Report/report-20150420/China-2050-High-Renewable-EnergyPenetration-Scenario-and-Roadmap-Study-Executive-Summary.pdf.

Gambhir, A., Tse, L. K. C., Tong, D. and Martinez-Botas, R. (2015), Reducing China's road transport sector $\mathrm{CO}_{2}$ emissions to 2050: Technologies, costs and decomposition analysis, Applied Energy, 157: 905-917. doi: 10.1016/j. apenergy.2015.01.018.

Garnaut, R. (2014), China's role in global climate change mitigation, China and World Economy, 22(5): 2-18. doi: 10.1111/j.1749-124X.2014.12081.x.

Garnaut, R. and Song, L. (2006), The turning point in China's economic development, Canberra: ANU E Press/Asia Pacific Press.

Garnaut, R., Song, L. and Cai, F. (2013), China's new strategy for long-term growth and development, in L. Song, R. Garnaut and F. Cai (eds), China: A new model for growth and development, pp. 1-16, Canberra: ANU E Press.

Garnaut, R., Song, L. and Cai, F. (2014), Reform and China's long-term growth and development, in L. Song, R. Garnaut and F. Cai (eds), Deepening reform for China's long-term growth and development, pp. 3-26, Canberra: ANU Press.

Global Commission on the Economy and Climate (2014), China and the new climate economy: China case study-Executive summary, Beijing: Tsinghua University. Available from: newclimateeconomy.net/sites/default/files/chinance-exec-summary-eng_reduced_1.pdf.

Green, F. \& Stern, N. (forthcoming), A new development model for China: Turning points for growth, urbanisation and environment, Policy Paper, London: Grantham Research Institute on Climate Change and the Environment and Centre for Climate Change Economics and Policy.

Green, F. and Stern, N. (2014), An innovative and sustainable growth path for China: A critical decade, Policy Paper, London: Grantham Research Institute on Climate Change and the Environment and Centre for Climate Change Economics and Policy. Available from: lse.ac.uk/GranthamInstitute/ publication/an-innovative-and-sustainable-growth-path-for-china-acritical-decade/. 
Green, F. and Stern, N. (2015), China's 'new normal': Structural change, better growth, and peak emissions, Policy Brief, London: Grantham Research Institute on Climate Change and the Environment and Centre for Climate Change Economics and Policy. Available from: lse.ac.uk/GranthamInstitute/ wp-content/uploads/2015/06/China_new_normal_webl.pdf.

Green F. and Stern, N. (2016), China's changing economy: Implications for its carbon dioxide emissions, Climate Policy, 16 March. Available from: tandfonline.com/doi/full/10.1080/14693062.2016.1156515.

Grubb, M., Sha, F., Spencer, T., Hughes, N., Zhang, Z. and Agnolucci, P. (2015), A review of Chinese $\mathrm{CO}_{2}$ emission projections to 2030: The role of economic structure and policy, Climate Policy, 15(S1): S7-S39. doi: 10.1080/14693062.2015.1101307.

Guan, D., Klasen, S., Hubacek, K., Feng, K., Liu, Z., He, K., Geng, Y. and Zhang, Q. (2014), Determinants of stagnating carbon intensity in China, Nature Climate Change, 4(11): 1017-1023. Available from: doi.org/10.1038/nclimate2388.

Hove, A., Enoe, M. and Gordon, K. (2015), China's next opportunity: Sustainable economic transition, Beijing: Paulson Institute.

$\mathrm{Hu}$, A. (2015), Embracing China's 'new normal': Why the economy is still on track, Foreign Affairs, 94(3): 8-12. Available from: foreignaffairs.com/articles/ china/2015-04-20/embracing-chinas-new-normal.

Huang, Y. and Cai, F. (2014), Debating the Lewisian turning point in China, London: Routledge.

International Monetary Fund (IMF) (2015), People's Republic of China: Staff report for the 2015 Article IV consultation, Washington, DC: International Monetary Fund. Available from: imf.org/external/pubs/ft/scr/2015/cr15234. pdf.

Jiang, K. (2014), China's $\mathrm{CO}_{2}$ emission scenario toward 2 degree global target, Presentation to Victoria University Conference on Abrupt Change in China's Energy Path: Implications for China, Australia and the Global Climate, Melbourne, 26 June. Available from: vu.edu.au/sites/default/files/cses/pdfs/ Kejun_2014_China's_CO2_emission_scenario.pdf.

Jiang, X. (2013), The rise of carbon emissions trading in China: A panacea for climate change?, Climate and Development, 6(2): 111-121. 
Johansson, Å., Guillemette, Y., Murtin, F., Turner, D., Nicoletti, G., de la Maisonneuve, C., Bagnoli, P., Bousquet, G. and Spinelli, F. (2013), Long-term growth scenarios, Economics Department Working Papers No. 1000, Paris: Organisation for Economic Co-operation and Development. Available from: search.oecd.org/officialdocuments/publicdisplaydocumentpdf/?cote $=\mathrm{ECO} /$ $\mathrm{WKP}(2012) 77 \&$ docLanguage $=$ En.

Jotzo, F. and Löschel, A. (2014), Emissions trading in China: Emerging experiences and international lessons, Energy Policy, 75: 3-8.

King, E. (2016), China will 'far surpass' 2020 climate target, says top envoy, Climate Home, 24 February. Available from: climatechangenews.com/2016/02/24/ china-will-far-surpass-2020-climate-target-says-top-envoy/.

Kong, B. and Freeman, C. (2013), Making sense of carbon market development in China, Carbon \& Climate Law Review, 7(3): 194-212.

Kuijs, L. (2015), Plan aims to balance growth with reform, China Daily [USA], 4 November. Available from: usa.chinadaily.com.cn/.

Lewis, A. (1954), Economic development with unlimited supplies of labour, The Manchester School, 22: 139-191.

Lewis, J. (2011), Energy and climate goals of China's 12th Five-Year Plan. Arlington, Va.: Pew Centre on Global Climate Change. Available from: c2es. org/docUploads/energy-climate-goals-china-twelfth-five-year-plan.pdf.

Li, H., Zhao, X., Ma, L. and Qi, Y. (2013), Policy implementation: Energy conservation target responsibility system, in Y. Qi (ed.), Annual review of lowcarbon development in China, pp. 78-150, Beijing: Social Sciences Academic Press.

Lo, A. Y. (2013), Carbon trading in a socialist market economy: Can China make a difference?, Ecological Economics, 87: 72-74.

Lo, A. Y. (2015), Challenges to the development of carbon markets in China, Climate Policy, 16(1): 109-124.

Lo, A. Y. and Howes, M. (2014), Powered by the state or finance? The organization of China's carbon markets, Eurasian Geography and Economics, 54(4): 386-408.

Mai, Y. and Feng, S. (2013), Increasing China's coal-fired power generation efficiency: The impact on carbon intensity and the broader Chinese economy to 2020, Paper presented to State Information Centre and National Development and Reform Commission Workshop, Beijing. 
Mathews, J. and Tan, H. (2014), Manufacture renewables to build energy security, Nature, 513: 166-168.

Myllyvirta, L., Shen, X. and Lammi, H. (2015), Is China doubling down on its coal power bubble?, Beijing: Greenpeace East Asia. Available from: greenpeace. org/eastasia/publications/reports/climate-energy/climate-energy-2015/ doubling-down/.

Nahm, J. and Steinfeld, E. S. (2014), Scale-up nation: China's specialization in innovative manufacturing, World Development, 54: 288-300. Available from: doi.org/10.1016/j.worlddev.2013.09.003.

National Bureau of Statistics (NBS) (2015a), China Statistical Yearbook 2015, Beijing: China Statistics Press.

National Bureau of Statistics (NBS) (2015b), Statistical communiqué of the People's Republic of China on the 2014 national economic and social development, Beijing: National Bureau of Statistics. Available from: stats.gov.cn/english/ PressRelease/201502/t20150228_687439.html.

National Bureau of Statistics (NBS) (2016), Statistical communiqué of the People's Republic of China on the 2015 national economic and social development, Beijing: National Bureau of Statistics. Available from: stats.gov.cn/english/ PressRelease/201602/t20160229_1324019.html.

Ng, S., Mabey, N. and Gaventa, J. (2016), Pulling ahead on clean technology: China's 13th Five Year Plan challenges Europe's low carbon competitiveness, Briefing Paper, London: E3G. Available from: e3g.org/docs/E3G_Report_on_ Chinas_13th_5_Year_Plan.pdf.

Olson, B. and Spegele, B. (2016), China slowdown stokes fears of peak oil demand, The Wall Street Journal, 25 January. Available from: wsj.com/articles/chinaslowdown-stokes-fears-on-peak-oil-demand-1453736237.

People's Bank of China (PBC) and United Nations Environment Programme (UNEP) (2015), Establishing China's green financial system, Final Report of the Green Finance Task Force, April, Nairobi: UNEP. Available from: unep. org/inquiry/PBC/tabid/1060068/Default.aspx.

People's Republic of China (PRC) (2015), Enhanced actions on climate change: China's intended nationally determined contributions, New York: UNFCCC. Available from: www4.unfccc.int/submissions/INDC/Published $\% 20$ Documents/China/1/China's\%20INDC\% 20-\%20on \% 2030\%20June \% 20 2015.pdf. 
Pettis, M. (2013), Avoiding the fall: China's economic restructuring, Washington, DC: Carnegie Endowment for International Peace.

Plumer, B. (2016), The real war on coal is happening in China right now, Vox, 6 March. Available from: vox.com/2016/3/6/11168914/china-peak-coal.

Pritchett, L. and Summers, L. H. (2014), Asiaphoria meets regression to the mean, NBER Working Paper No. 20573, Cambridge, Mass.: National Bureau of Economic Research. Available from: nber.org/papers/w20573.

Reed, S. (2015), China raises its targets for renewable energy, The New York Times, 8 December. Available from: nytimes.com/interactive/projects/cp/ climate/2015-paris-climate-talks/china-raises-its-targets-for-renewableenergy.

Reklev, S. (2016a), China sets $18 \%$ carbon intensity reduction target by 2020 , Carbon Pulse, 5 March. Available from: carbon-pulse.com/16618/.

Reklev, S. (2016b), China national ETS launch likely in second half of 2017, Carbon Pulse, 15 March. Available from: carbon-pulse.com/17057/.

Schafer, A. (2005), Structural change in energy use, Energy Policy, 33: 429-437.

Sheehan, P., Cheng, E., English, A. and Sun, F. (2014), China's response to the air pollution shock, Nature Climate Change, 4(5): 306-309. Available from: doi. org/10.1038/nclimate2197.

Shen, W. (2014), Chinese business at the dawn of its domestic emissions trading scheme: Incentives and barriers to participation in carbon trading, Climate Policy, 15(3): 339-354.

Shen, Y. (2013), Moving steadily or great leap forward? The emerging carbon market in China, Deakin Law Review, 18(2): 233-270.

Song, R., Dong, W., Zhu, J., Zhao, X. and Wang, Y.(2015), Assessing implementation of China's climate policies in the 12th 5-year period, September, Working Paper, Washington, DC: World Resources Institute.

Spencer, T. (2016), Chinese coal? What does it mean for the Paris Agreement?, IDDRI Blog, 12 February, Paris: Institute for Sustainable Development and International Relations. Available from: blog-iddri.org/en/2016/02/12/ chinese-coal-what-does-it-mean-for-the-paris-agreement/.

State Council of the People's Republic of China (State Council) (2007), Implementation plan for the performance evaluation system of energy consumption per unit of GDP, Beijing: State Council of the People's Republic of China. 
State Council of the People's Republic of China (State Council) (2013), Air pollution prevention and control plan, Beijing: State Council of the People's Republic of China.

Stern, N. (2011), Raising consumption, maintaining growth and reducing emissions: The objectives and challenges of China's radical change in strategy and its implications for the world economy, World Economics, 12(4): 13-34.

Teng, F., Xin W. and Lv, Z. (2014), Introducing the emissions trading system to China's electricity sector: Challenges and opportunities, Energy Policy: 1-7.

The Economist (2014), Generational shift, The Economist, 25 October. Available from: economist.com/news/china/21627626-china-developing-cleansources-energy-problem-getting-them-used-generational-shift.

Wang, Z., Qin, H. and Lewis, J. (2012), China's wind power industry: Policy support, technological achievements, and emerging challenges, Energy Policy, 51: 80-88.

Wilson, R. (2015), Peak coal in China? Not so fast, Carbon Counter Blog, 27 February. Available from: carboncounter.wordpress.com/2015/02/27/ peak-coal-in-china-not-so-fast/.

Wolf, M.(2015), Why worries about China make sense, Financial Times, 25 August. Available from: ft.com/cms/s/0/edd707ba-4a56-11e5-9b5d-89a026fda5c9. html??ftcamp $=\mathrm{crm} / \mathrm{email} / / \mathrm{nbe} /$ FirstFTEurope/product\#axzz3jgMhxWRg.

World Bank (2016), GDP growth (annual \%), Washington, DC: The World Bank. Available from: data.worldbank.org/indicator/NY.GDP.MKTP.KD.ZG.

World Bank and Development Research Centre of the State Council, People's Republic of China (DRC) (2014), Urban China: Toward efficient, inclusive, and sustainable urbanization, Washington, DC: The World Bank.

World Nuclear Association (2016), Nuclear power in China, London: World Nuclear Association. Available from: world-nuclear.org/information-library/ country-profiles/countries-a-f/china-nuclear-power.aspx.

Wynn, G. (2015), China's carbon emissions: Did they really fall in 2014?, Responding to Climate Change, 16 February. Available from: rtcc.org/2015/02/16/chinascarbon-emissions-did-they-really-fall-in-2014/\#sthash.eIHJOsEd.dpuf.

Xinhua (2015), 'Made in China 2025' plan unveiled, Xinhua, 19 May. Available from: chinadaily.com.cn/bizchina/2015-05/19/content_20760528.htm. 
Xu, X., Zhao, T., Liu, N. and Kang, J. (2014), Changes of energy-related GHG emissions in China: An empirical analysis from sectoral perspective, Applied Energy, 132: 298-307. doi: 10.1016/j.apenergy.2014.07.025.

Yu, X. and Lo, A. Y. (2015), Carbon finance and the carbon market in China, Nature Publishing Group, 5(1): 15-16.

Zhang, D., Karplus, V. J., Cassisa, C. and Zhang, X. (2014), Emissions trading in China: Progress and prospects, Energy Policy, 75: 9-16.

Zhang, G. (2014), Comprehensively deepen reforms to promote sustainable and healthy development of the economy and society, Speech at the 15th China Development Forum, Beijing, 23 March. Available from: cpc.people.com. cn/n/2014/0324/c64094-24714056.html.

Zhang, S., Andrews-Speed, P. and Ji, M. (2014), The erratic path of the lowcarbon transition in China: Evolution of solar PV policy, Energy Policy, 67: 903-12.

Zhang, Z. (2015), Carbon emissions trading in China: The evolution from pilots to a nationwide scheme, Climate Policy, 15(S1): S104-S126.

Zhao, X. and Ortolano, L. (2010), Implementing China's national energy conservation policies at state-owned electric power generation plants, Energy Policy, 38(10): 6293-6306.

Zhao, X., Li, H. and Wu, L. (2015), Enterprise-level energy savings targets in China: Compliance, weaknesses, and the way forward, Unpublished ms. 
This text is taken from China's New Sources of Economic Growth: Reform, resources and climate change, Volume 1, edited by Ligang Song, Ross Garnaut, Cai Fang \& Lauren Johnston, published 2016 by ANU Press, The Australian National University, Canberra, Australia. 